\title{
Waldorf teacher education: Historical origins, its current situation as a higher education training course, and the case of Spain
}

\author{
La formación de los docentes Waldorf: orígenes históricos, su situación actual \\ como formación de educación superior, y el caso de España
}

\begin{abstract}
La Formation pédagogique Waldorf : ses origines historiques, sa situation actuelle comme cours de formation à l'enseignement supérieur, et le cas de l’Espagne
\end{abstract}

\section{Patricia Quiroga Uceda}

Independent researcher, Spain

\section{ABSTRACT}

Waldorf schools base their pedagogical practice on the ideas of Rudolf Steiner (18611925), namely on the esoteric philosophy of anthroposophy he founded in 1913. This paper discusses how Waldorf school teachers are trained. It starts by analyzing the first training course Steiner taught for the teachers at the Freie Waldorfschule, the first Waldorf School, founded in Stuttgart in 1919. It then goes on to examine the structure and theoretical underpinnings of Waldorf teacher training today. Finally, it looks at the specific case of the "Training Course in Waldorf Pedagogy and Humanistic-Artistic Education" given to Waldorf teachers in Spain. The main conclusion reached is that the structure of teacher training for Waldorf schools consists of giving an initial theoretical approach to anthroposophy, which lays the groundwork on which to base pedagogical practice. This involves having teachers integrate the categories of anthroposophy into their training process before acquiring the knowledge and skills required for carrying out their teaching endeavors.

Key words: higher education, Waldorf teacher training, Rudolf Steiner, anthroposophy, Social Threefolding, Waldorf schools.

\section{RESUMEN}

Las escuelas Waldorf fundamentan su práctica pedagógica en el pensamiento de Rudolf Steiner (1861-1925) y concretamente, en la corriente esotérica de la antroposofía que fundó en 1913. En este artículo se aborda la formación de los docentes de las escuelas 
Waldorf. Para ello, un primer elemento de análisis lo constituye el primer curso de formación que Steiner impartió a los docentes de la primera escuela, la Freie Waldorfschule, fundada en 1919 en Stuttgart (Alemania). A continuación se examina la estructura y la fundamentación teórica a la que responde la formación de docentes Waldorf en la actualidad. Finalmente, se estudia el caso concreto del Curso de Formación en Pedagogía Waldorf y Formación Humanístico-Artística de formación de docentes Waldorf que se imparte en España. La principal conclusión es que para la estructuración de la formación de docentes para las escuelas Waldorf se parte de un primer acercamiento al marco teórico de la antroposofía que es la base sobre la que se fundamenta la práctica pedagógica. Se trata de que los docentes en su proceso de formación integren las categorías propias de la antroposofía con anterioridad al aprendizaje de los conocimientos y habilidades vinculados con el desempeño docente.

Descriptores: educación superior, cursos de formación para docentes Waldorf, Rudolf Steiner, antroposofía, Triformación Social, escuelas Waldorf.

\section{RESUME}

Les écoles Waldorf basent leur pratique pédagogique sur les idées de Rudolf Steiner (1860-1925), notamment sur la philosophie ésotérique de l'anthroposophie qu'il fonda en 1913. Cet article examine comment les enseignants des écoles Waldorf sont formés. L'auteur commence par analyser le premier cours de formation enseigné par Steiner aux enseignants à la Freie Waldorf Schule, la première école Waldorf, fondée à Stuttgart en 1919. Il examine ensuite la structure et les supports théoriques de la formation Waldorf des enseignants aujourd'hui. Enfin il considère le cas spécifique du «Cours de formation en Pédagogie Waldorf et en Éducation humaniste-artistique» donné aux enseignants Waldorf en Espagne. Sa conclusion principale : La structure de la formation pédagogique pour les écoles Waldorf consiste à donner à l'anthroposophie une approche théorique initiale. Celle-ci pose le fondement pour la pratique pédagogique. Cette approche comprend l'intégration des catégories anthroposophiques par les enseignants dans leur processus de formation avant l'acquisition des connaissances et des habiletés requises pour effectuer leurs efforts pédagogiques.

Mots clés : L'enseignement supérieur, Les cours de formation des enseignants Waldorf, Rudolf Steiner, L'anthroposophie, Le «Triple social», Écoles Waldorf.

Waldorf education is a fairly unique option in education for two reasons. First, it is a "signature pedagogy," since the fundamental underpinning governing these centers is the philosophy and thought of Rudolf Steiner (1861-1925) (Quiroga, 2014). And second, their teachers must be given a specific higher education complementary to the education acquired at official institutions. Certification from these courses enables them to work at any Waldorf school in the world, which currently number 1,063 schools in 61 
countries. The number of teaching centers has also increased accordingly, now at a total of 142 (Freunde der Erziehungskunst Rudolf Steiners, 2015). Waldorf schools are mainly private, although there is a degree of variety in ownership in accordance with the educational policies of each country.

The study of teacher training for Waldorf schools is best begun by setting it in Steiner's works, specifically in the study of anthroposophy, which he created in 1913. Roughly speaking, anthroposophy - also known as Spiritual Science - is a Western esoteric $^{1}$ philosophy composed of Steiner's philosophical and religious ideas, which attempt to explain human beings and the world at large based on material and esotericspiritual aspects. One of the main features of anthroposophy is the viewpoint of human beings as made up of a body, soul, and spirit. This metaphysical conception takes on great relevance in education, since the aim becomes to attend to all three aspects. Waldorf pedagogy is therefore considered to be transcendental in nature (Quintana, 2013, pp. XCV-CVIII). With anthroposophy, Steiner wished to balance out the materialistic perspective he found overly dominant in his day. In that sense, he once stated that what had been corrupted the most by this wave of materialism was teacher training (Steiner, 2008, p. 64).

The research questions that articulate this paper are as follows. What theoretical basis and structure are found in training teachers in anthroposophical pedagogy, taking as a reference the historical analysis of the origins of the first Waldorf school and the pedagogical notions Rudolf Steiner developed for his first faculty meeting at the center in Stuttgart in 1919? What pedagogical notions act as the scaffolding on which Waldorf teacher training is articulated today? What particular characteristics are featured in the specific case of the "Training Course on Waldorf Pedagogy and Humanistic-Artistic Education" (Curso de Formación en Pedagogía Waldorf y Formación HumanísticoArtística) in Spain?

To answer these questions, this paper has been structured into three parts, each of which deals with one of the above questions. The first part studies the foundation of the first educational center where Waldorf pedagogy was developed, the Freie Waldorfschule, and the training course Steiner himself gave to its teachers. The second part delves more deeply into the structure and theoretical underpinnings of Waldorf teacher training today. This is done by examining matters such as the institutions where these courses are given, their official certification, the profile of the trainers, the criteria for accessing the course, and the duration of the course. Finally, an examination is made of the "Training Course on Waldorf Pedagogy and Humanistic-Artistic Education" taught at the Centro de Formación en Pedagogía Waldorf at the Escuela Libre Micael in Madrid.

\footnotetext{
${ }^{1}$ The term "esoteric" here refers to any knowledge that is hidden from the human mind and must be accessed by a degree of initiation. Anthroposophy is a Western esoteric philosophy whose founder and initiator was Rudolf Steiner. Its doctrines and philosophy are studied and developed in the Anthroposophical Society. Steiner tried to make a difference between anthroposophy and other esoteric philosophies by pointing out that "dormant in everyone are faculties by which we can acquire knowledge of higher worlds" (Steiner, 2002, p. 15). He believed that with constant personal effort, one could "awaken the spiritual eye" and become clairvoyant. The best tool to attain clairvoyance is his book How to Know Higher Worlds (1909).
} 


\section{The Freie Waldorfschule and the first training course for Waldorf teachers}

The context in which the first Waldorf school was founded is fairly well known. In 1919, Emil Molt was the manager of the Waldorf-Astoria cigarette factory and close collaborator with Steiner in the Anthroposophical cause. One of the most noteworthy projects in which Steiner and Molt collaborated was "Social Threefolding," a social theory they tried to apply to the context of World War I to offset the destruction from the war (Uhrmacher, 1995, p. 383). Social Threefolding proposed a threefold order based on the idea that, much like the organism of human beings, the organism of society is made up of interdependent systems, each of which satisfies a certain need. These three social systems were politics, which was to be governed by equality; the economy, to be governed by fraternity; and culture, to be governed by liberty. Steiner felt that the liberté, égalité, fraternité motto of the French Revolution had not been applied correctly, so his theory proposed extending the motto to form the basis of a new society that would bring about a renewal of spiritual life in mankind (Eaton, 1984, pp. 425-500). With Social Threefolding, Steiner was joining ranks with a feeling that had spread across Europe in a number of social and cultural movements voicing slogans for pacifism, feminism, and socialism that prompted thinking of new bases for society (Blom, 2010, p. 286). His intention of implementing this social order, however, was of little interest to the political class.

This fiasco greatly affected Molt, who went on thinking of the need to found some kind of anthroposophical project that would change how society was organized. The opportunity arose after an employee confided how happy he was that his son had been recommended to continue his education at the secondary level. Molt recognized that he felt "the tragedy of the working class" (Molt, in Murphy, 1991, p. 137) in that needy families could not afford to give their children a proper education. In the economic context of a stratified society in the early $20^{\text {th }}$ century, schooling set its criteria for exclusivity, but it was also perceived as an important path to upward social mobility (Hobsbawm, 2012, pp. 183-190).

After failing to implement the social threefolding concept, the only option left seemed to be that of letting its principles gradually enter society by means of more specific, clearly defined projects. Education was a matter of great concern to Molt, and after his conversation with his employee, in April 1919, he met with Steiner and suggested they found a school that would be based on anthroposophy and would be intended for their workers' children. Molt's intention was for Steiner, as the leader and founder of the anthroposophy movement, to take charge of pedagogy at the school (Molt, in Murphy, 1991, p. 138). Steiner accepted. Intending to start up the education project within their five-month deadline, Molt took charge of handling the paperwork at the Ministry of Culture in Stuttgart. Steiner took the reins on pedagogy. The first task was to find suitable future teachers. Along with another collaborator, Karl Stockmeyer, they were able to take on twelve people, all middle aged and from a variety of professional backgrounds. They heralded from Germany, Austria, and the Baltic provinces. They were theologians, philologists, mathematicians, naturalists, doctors, gym teachers, engineers, and artists (painters, musicians, eurhythmics teachers, and 
craftsmen) (Hartlieb, 1928, p. 29). Even though they were not practicing teachers, one essential aspect was that most were already familiar with anthroposophy. This let Steiner develop a conceptually highly complex training course for anyone who was lacking in such prior knowledge. ${ }^{2}$

Steiner designed an intensive training curriculum that covered different aspects of anthroposophy and education for the two weeks before the school opened, from 21 August to 6 September 1919. The organization of that training course can be seen in how the school day was split up: from 9:00 to 10:30 am, the lectures were on Anthroposophical anthropology; from 10:30 am to $1: 00 \mathrm{pm}$, on teaching and methodology; and in the afternoon, from 3:00 to 6:00 pm, colloquiums were held on different topics that Steiner posed to the teachers, such as "their tasks in class, school organization and planning the teaching" (Steiner, 2010, p. 6). The lectures are published together in three works: Study of Man: General Education Course, Practical Advice to Teachers, and Discussions with Teachers, respectively. ${ }^{3}$ These publications still make up the basic study material for Waldorf teachers today.

For Steiner, the meaningfulness of founding the school fits in clear continuity with his theory of Social Threefolding. Moreover, the Freie Waldorfschule was the first project in which theoretical knowledge from anthroposophy was applied to a practical area of life. The importance Steiner gave to this institution can be seen in the welcome speech he gave to the participants in the course on 20 August 1919. On this occasion, Steiner noted:

The Waldorf School must be a real cultural deed, one that can bring about a renewal of the spiritual life of the present time. We have to realize that everything is going to change; the whole of the social movement, fundamentally, has its source in the spirit, and the question of Education is also a part of the burning questions of our time. Waldorf education must be taken as an opportunity to reform and revolutionize Education.

The success of this cultural deed is in your hands. This gives you a tremendous opportunity for setting an example (...) The Waldorf School will be practical proof of the success of Anthroposophy. (Steiner, 1919, p. 34)

For Steiner, the founding of the Waldorf School was an event that he described as being "of cosmic dimensions" (Steiner, 2014, p. 8) and thus he aspired to it being

\footnotetext{
${ }^{2}$ A significant work on this matter is found in Mazzone, A. (1999). Waldorf teacher education: The implications for teacher education of Rudolf Steiner's educational philosophy and its practice in Waldorf schools (PhD dissertation). University of Adelaide.

${ }^{3}$ In Spanish, these books are Fundamentos de la Educación Waldorf I: El Estudio del Hombre como Base para la Pedagogía (2014), Fundamentos de la Educación Waldorf II: Metodología y Didáctica (2006), and Coloquios Pedagógicos y Conferencias Curriculares (2010).
} 
constituted as a space that, given the social problems of his day, would improve the conditions of mankind. And all of it fell under the umbrella heading of anthroposophy.

Indeed, Waldorf pedagogy was conceived for a very specific time in history: the stage of the "Consciousness Soul" (1413 AD to 3573 AD). According to Steiner, at this time, human beings freely and by means of spiritual work decided to go back to living with the presence of the spiritual world. All this meant embarking on a new ascent towards the heavens. In this scheme, Waldorf pedagogy hoped to develop the Ego in the young boys and girls, and the theory of the seven-year cycles was the best theoretical framework for doing so. This theory divided human life into seven-year cycles based on very specific characteristics that converge in each cycle. Thus, the cycles that are developed in the stage of schooling are the first three. The first (from 0 to 7 years old) is the time for developing the physical body, ${ }^{4}$ the second (7 to 14) is for the etheric body, ${ }^{5}$ and the third (14 to 21 ) is the astral body. ${ }^{6}$ Little by little, the ego ${ }^{7}$ developed further at that time and if it attended to the special needs of the physical, etheric, and astral body, it would have developed in good health. Its emancipation then proceeded at the age of 21 (Steiner, 1991).

Convinced that working on the basis of anthroposophy would demand a commitment professionally, Steiner looked for teachers by trying to appeal to their individual conscience and responsibility. This fact is closely related to the "ethical individualism" Steiner had developed many years prior, in which every person had a responsibility to the unfolding of history. ${ }^{8}$ Thus, Steiner continued his speech, pointing out:

The School, therefore, will have its own administration run on a republican basis and will not be administered from above. We must not lean back and rest securely on the orders of a headmaster; we must be a republic of teachers and kindle in ourselves the strength that will enable us to do what we have to do with full responsibility. Each one of you, as an individual, has to be fully responsible.

\footnotetext{
${ }^{4}$ In anthroposophy, the physical body is a person's external body. The first cycle is considered as the time when that human body is being formed and the bases set for future development. Steiner considered that at this time, "the child is all sense organ" (Steiner, 1991, p. 58). Therefore, Waldorf pedagogy pays special attention to the qualities of the boys' and girls' environment and to the behavior of the adults.

${ }^{5}$ The physical body is considered to be the architect of the etheric body, since it consists of a sheath of energy that produces our vital phenomena. Anthroposophy interprets second dentition as the time it stops. After that, children undergo physiological changes that strengthen their breathing and pulse (Steiner, 2004, p. 144). In terms of education, it is a time for teaching with images and rhythms.

${ }^{6}$ The astral body is the vehicle for emotive life. This body emerges at the age of 14 and is accompanied by new qualities of independent judgment and the quest for truth. In Waldorf pedagogy, this is the time to work on academic contents by means of abstraction (Steiner, 1991, pp. 43-44).

${ }^{7}$ To Steiner, the ego was "the expression of the higher soul, and because we possess it, human beings are at the top of creation." Its function was thus "to make the physical, etheric, and astral body more noble and pure" (Steiner, 1991, p. 17).

${ }^{8}$ The development of ethical individualism can be found in Steiner, R. (2002). La filosofía de la libertad. Madrid, Spain: Editorial Rudolf Steiner.
} 
We will replace the duties of a headmaster by having this preparatory course in which we will work to acquire the spirit that will unite the School. If we work hard, this course will engender in us our spirit of unity. (Steiner, 1919, p. 34)

Steiner's wish for the center to create a "spirit that will unite the School" went beyond the faculty's having good working relations or the decision-making process working as a republic of teachers. In his words, Steiner was indicating that anthroposophy had to be the foundation of the daily work at the center, a foundation that was not restricted to the specific methodology and pedagogy that would become typical of the Waldorf school. Rather, Steiner was appealing to each teacher individually and all together as a faculty. Thus, every Waldorf teacher individually had to see himself in constant self-education, understood as a process of refining one's character. Regarding the faculty as a whole, the teachers would meet weekly with two objectives: to further the study of anthroposophy and to tackle concrete questions that derive from practice. ${ }^{9}$ As scheduled, the Freie Waldorfschule opened its doors on 7 September 1919. It soon became evident that the school year was started off in haste and that many matters had not yet been settled. Later on, over time and with Steiner giving his guidance at the meetings held periodically, the more general theoretical principles became more meaningful, which led to developing ties with the practice and day-to-day aspects of the classroom. ${ }^{10}$ In any case, it also became clear at this time that the Anthroposophical underpinnings of Waldorf pedagogy meant that being a Waldorf teacher was something that had to be learned and continuously updated.

\section{The preparation and training of contemporary Waldorf teachers}

In the nearly 100 years since the Freie Waldorfschule first opened, Waldorf pedagogy spread, attending to overlapping processes of explicit prohibition and rapid expansion (Quiroga \& Girard, 2015). The way anthroposophy and its pedagogic offshoot were implemented in each cultural context or region so as to propitiate the opening of teacher training centers is a subject matter far beyond the scope of this paper. The complexity of the studies on its reception, even in cases in which the object of study is the reception of a scientific theory in a particular cultural context (Livingstone, 2004), is well known. Therefore, the purpose of this paper is limited to presenting a somewhat

\footnotetext{
${ }^{9}$ Although the exact date when these weekly faculty meetings first started is unknown, the practice continues today. Interestingly, the meetings are always held on Thursdays since that is the day when planetary forces were projected by Jupiter, which Steiner believed symbolized the wisdom that needed to be transformed into love (Henk van Oort, 2011, pp. 63-64)

${ }^{10}$ Those meetings were written up in various publications. One interesting example is the collection Rudolf Steiner's Conferences with the Teachers of the Waldorf School in Stuttgart. Gathered in four volumes, each one belongs to the school courses Steiner was able to take part in at the center before his death. Steiner, R. (1986). Rudolf Steiner's Conferences with the Teachers of the Waldorf School in Stuttgart. 1919-1920. Vol. 1.; (1987). 1921-1922. Vol. 2; (1988). 1922-1923. Vol. 3; (1989). 1923-1924. Vol. 4. Forest Row, England: Steiner School Fellowship Publications.
} 
schematic map of the processes involved in preparing and training Waldorf teachers institutionally in different national contexts.

From the years following the inauguration of the school in Stuttgart up to his death in 1925, Steiner continued giving conferences on anthroposophy in which he often mentioned the newly created school. The school also received visitors who wanted to find out about the pedagogy. These two dynamics led to groups of people interested in opening a Waldorf school to ask Steiner to give a series of conferences specifically for teachers along the same lines as the original faculty training course from 1919. By the time of his death in 1925, Steiner had taught several series and five new schools had opened. Two of them were located in Germany: the Freie Goethe-Schule and the Waldorf School in Essen. ${ }^{11}$ Three other centers were founded beyond the German borders: the Friedwart School in Basel (Switzerland) in 1920, the Vrije School Den Haag in the Hague (Netherlands) in 1923, and Michael Hall School in London (UK) in 1925 (Werner \& von Plato, 2001, p 26).

After the death of the leader, the dynamics of Waldorf teacher training were forced to find new ways, since the schoolteachers themselves were now the ones best versed in this type of teaching, and the ones who naturally took on the training of future teachers. The first two teacher training centers were created in two core anthroposophical activities par excellence. The first was the Freie Hochschule Stuttgart - Seminar für Waldorfpädagogik in Stuttgart, which started in 1928,12 and the second was formed in 1957 at the site of the Goetheanum, the headquarters of the World Anthroposophical Society in Dornach (Switzerland). It was not until the 1960s that new schools were opened in England (1962), the United States (1967), and Sweden (1968) (Werner \& von Plato, 2001, p. 28).

An understanding of the process for opening teacher training centers first requires some knowledge of how Waldorf pedagogy was received. The creation of a teacher training center is a late step in this process, on account of the highly demanding initial conditions: infrastructure, a faculty, and enough students interested to make it feasible. Generally, the first milestone in receiving Waldorf pedagogy is to found an educational initiative with a small number of people interested in Anthroposophy and pedagogy alike. The teachers in this first initiative are usually trained abroad in nearby countries with a tradition of Waldorf pedagogy. As demand at these schools grows and more teachers are needed, the conditions become suitable for opening and maintaining teacher training centers. This fact is indicative of how consolidated Waldorf pedagogy is in a given country. At the same time, the fact of having a teacher training center adds to

\footnotetext{
${ }^{11}$ I have not been able to find the name of this school. As Staudenmaier points out, this school had internal problems and problems with the pedagogy movement itself. So much so, in fact, that in 1933 eight Waldorf schools were counted in Germany, and the Essen school was not one of them. It closed in 1936 (Staudenmaier, 2014, p. 183).

${ }^{12}$ This is the date given from the Freie Hochschule Stuttgart. Seminar für Waldorfpädagogik (2015). Other sources indicate that in the 1920s and 1930s, the training of Waldorf teachers fell to the faculty at the Stuttgart school, pointing to the opening of the teacher training center in 1951 (Werner \& von Plato, 2001, p. 28).
} 
the possibilities of expanding the pedagogic movement and reduces dependency on other countries.

Graphs 1 and 2 show the current presence of Waldorf schools and teacher training centers around the world. As stated earlier, there are a total of 1,063 schools in 61 different countries and 142 Waldorf teacher training centers (Freunde der Erziehungskunst Rudolf Steiners, 2015).

Graph 1: Number of Waldorf Schools by country, 2015

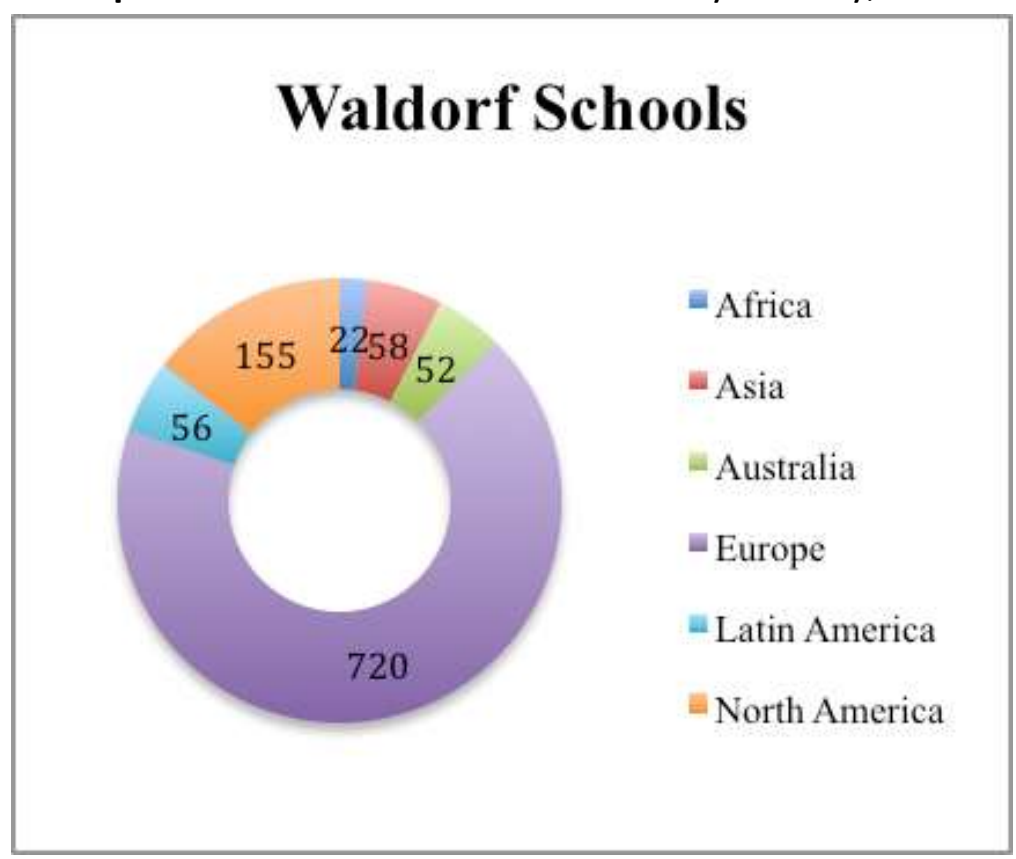

Source: Freunde der Erziehungskunst Rudolf Steiners, 2015.

Graph 2: Number of Waldorf training schools by country, 2015

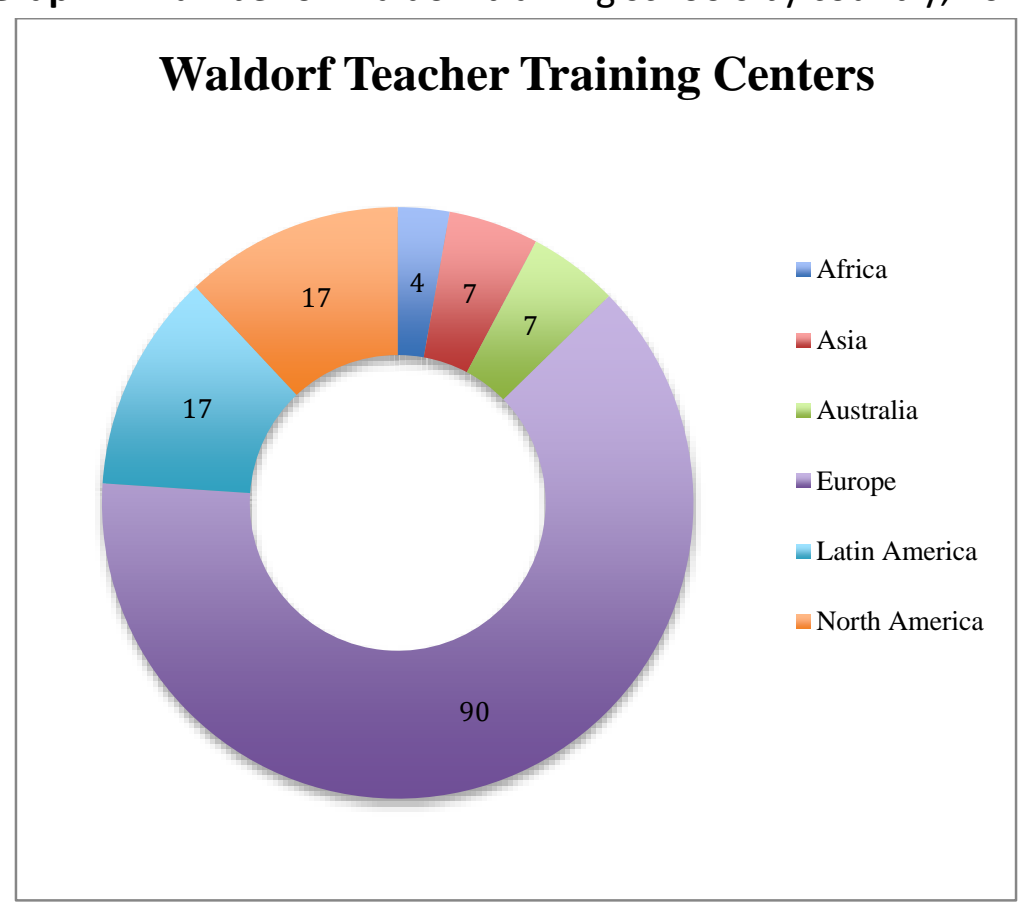

Source: Freunde der Erziehungskunst Rudolf Steiners, 2015. 
There is a great deal of heterogeneity in how Waldorf teacher training courses are designed and structured. This characteristic is consistent with Steiner's philosophy being interpreted differently in each cultural setting, as well as with the possibilities afforded by the legalities in each country. Nevertheless, there are many features that are common to all. First, the training centers are mostly organized from within the Waldorf pedagogy movement. They tend to use their own school facilities or Anthroposophical institutions. The universities that teach these training courses are truly exceptional in the world. Such is the case of Antioch University (USA), ${ }^{13}$ Alanus Hochschule für Kunst und Gesellschaft (Germany), ${ }^{14}$ David Yellin College of Education (Israel) - home to the Jerusalem Academy Waldorf Teacher Training, ${ }^{15}$ Auckland University of Technology School of Education (New Zealand), ${ }^{16}$ and the Centro Universitario LaSalle (Spain). ${ }^{17}$

The training courses normally have double approval: from the Waldorf pedagogy movement, and from the regulatory authority for education in each country. Thus, for instance, the programs taught at West Coast Institute for Studies in Anthroposophy in British Columbia (BC), Canada, are approved by the Association of Waldorf Schools of North America (AWSNA), the Independent Schools Branch of the BC Ministry of Education, and registered with the Private Career Training Institutes Agency of BC (PCTIA). ${ }^{18}$ This dual certification is due to the fact that Waldorf pedagogy as an education option seeks integration in the official system, so it has the certifications and accreditations required by government authorities. A noteworthy European initiative in this regard is the European Network for Academic Steiner Teacher Education (ENASTE). Founded in 2007, this organization and its main line of action advocate intensifying collaboration among European universities and educational institutes "offering academic accreditation for the Waldorf teach education programs" (ENASTE, 2015).

\footnotetext{
${ }^{13}$ Antioch University offers degrees in environmental studies and sustainability, health and social sciences, art, psychology, and education, among others. One of their programs in the field of education is the "Waldorf Certificate Program." http://www.antioch.edu

${ }^{14}$ This private university, which teaches in German and English, is also known as Alanus University of Arts and Social Sciences. Most of its degree programs involve art (architecture, sculpture, drawings, drama, eurhythmics, artistic therapies) and Waldorf education. This center was founded in 1973 as an institution for the study and teaching of Anthroposophy-based art. People interested in becoming Waldorf teachers can choose the "Bachelor's degree in Waldorf Education," "Master's degree in Waldorf education with a focus on class teaching," and the "Certificate Course in Waldorf Education." Moreover, this university collaborates with Waldorf teacher training centers such as Rudolf Steiner University College (Norway) and the Institute for Waldorf Education, Inclusion and Intercultural Studies in Mannheim. http://alanus.edu

${ }^{15}$ The David Yellin College of Education is a teacher training center. One of their Bachelor's degrees in education is the Waldorf Elementary Education Track. http://www.dyellin.ac.il/100/en/

${ }^{16}$ The Bachelor of Education at the Auckland University of Technology's School of Education offers third-year specialization in "Steiner Early Childhood Teaching" or "Steiner Primary Teaching."

http://www.aut.ac.nz/study-at-aut/study-areas/education

${ }^{17}$ At the university's Madrid and Barcelona campuses, they offer a graduate degree in Early Childhood Education.

http://www.lasallecentrouniversitario.es/estudios/programa posgrado/area educacion/waldorf/Paginas/def ault.aspx

${ }^{18}$ For more information, see: http://westcoastinstutute.org.
} 
The profile of Waldorf teacher trainers is that of people with extensive knowledge in anthroposophy and Waldorf pedagogy, plus a well-established career in the Waldorf classroom. As mentioned above, countries that are just beginning to implement educational initiatives rely much more heavily on the expertise of foreigners. This trend reverts naturally over time: as the Waldorf movement becomes consolidated, each country has more of its own national experts.

The admissions requirements to study these courses are also very heterogeneous. In most cases, they vary depending on the course. It is not the same to take a course like the one at Auckland University of Technology School of Education, where Waldorf education is integrated into teacher training and for which university entrance certificates are required, as it is to take an independent course separate from a degree in education, such as the one at the Centro de Formación en Pedagogía Waldorf in Madrid. Another feature that differentiates these courses is that some of them have a prerequisite in anthroposophy. In addition, there are centers that establish an admission process for students that is characterized by finding out certain aspects about the future teachers. Sometimes they are given an interview, asked to write a letter of motivation, required to provide a brief autobiography or their $\mathrm{CV}$, or to supply several letters of recommendation.

Waldorf teacher training courses are usually long and intense. The reason for the duration is that the study of anthroposophy itself takes a long time. Moreover, Waldorf pedagogy is not conceived simply as something to learn and apply. Instead, it is understood as being a path to inner development that helps the future teacher gradually become familiar with an esoteric-spiritual vision of human being, and a way to teach accordingly. In other words, the first step toward teaching is to be initiated in the knowledge from anthroposophy as a theoretical framework of reference. Therefore, the courses usually last two to four years. There is a multitude of courses offered depending on the center and country, and there is usually an option to study full time or part time. In some cases, such as at the Steiner Waldorf Schools Fellowship in England and Ireland, they offer several course options depending on the prior teaching and anthroposophical experience. ${ }^{19}$

These courses are generally composed of two parts: theory and practice. The theoretical part usually consists of attending conferences or talks, while the practical contents are mainly focused on activities that highlight how the theory is applied, as well as other artistic ones. There are also activities that are assigned to each future teacher. These tasks often involve readings (Steiner's conferences at the first faculty meeting along with his classic works ${ }^{20}$ are the main texts), writing different types of papers or projects, and doing practice teaching at Waldorf education centers. The contents of the course focus on knowledge of anthroposophy, human biography and its

\footnotetext{
19 The different options of available courses can be found at: http://www.steinerwaldorf.org/steinerteachers/teacher-education/.

${ }^{20}$ Some of his classic works are The Philosophy of Freedom (1894), Theosophy (1903), How to Know Higher Worlds (1909), and The Occult Science (1910).
} 
seven-year cycles, ${ }^{21}$ the educational principles at Waldorf schools, school organization, and the specific ways to teach the different subjects. In consonance with the philosophy behind Steiner and the Waldorf Schools, in Waldorf teacher training courses, formal exams are not seen as the most effective way to evaluate achievement.

Waldorf education is based on anthroposophy. This starting point means that any future teachers at these centers need to become familiar with a language and a set of categories that do not exist in the rest of the educational approaches. As such, the teacher training course may be conceptualized as an initiation process in anthroposophy and Waldorf pedagogy whereby the teachers integrate this view of mankind and education. In parallel, and due to its uniqueness, this pedagogy has created its own channels for development and spread, mainly through international congresses of Waldorf teachers. These meetings constitute an important event, since they help foster a feeling of community in an international movement among everyone participating in Waldorf schools. Furthermore, they provide valuable ongoing learning experiences for the teachers. Although there is a wide range of congresses, the most significant is the World Waldorf Teacher's Conference, jointly organized by the International Forum of Waldorf Steiner Schools, the Pedagogical Section, and the Hague Circle, and held every four years at the Goetheanum (Kullak-Ublick, 2014).

\section{The case of the "Training Course on Waldorf Pedagogy and Humanistic- Artistic Education" in Spain}

In Spain, anthroposophy and Waldorf pedagogy were received much later than elsewhere in Europe. At the end of the 1970s, a group of people began to study anthroposophy and to think about pedagogy (A. Malagón, interview, 21 January 2014). However, ideological repression under the Franco dictatorship and the imposition of Catholicism as the state religion did not set the conditions for developing this pedagogy much beyond the semi-clandestine channels (Quiroga, 2015). In the Spanish context, the first education center was founded in the incipient democratic period. It was the Jardín de Infancia Micael, a kindergarten that opened its doors in Madrid in 1979. That was also the year the Asociación de Colegios Waldorf was constituted, aimed at promoting and disseminating pedagogy. The first teachers at the kindergarten went to France and Germany for their training. In parallel with the opening of this educational initiative were a number of introductory courses on anthroposophy in the summers of 19781982. In these courses, which were mostly taught by foreigners, they worked on Waldorf pedagogy but also on the fundamentals of anthroposophy and its practical applications, such as on biodynamic agriculture, Social Threefolding, and the arts (M. Gómez, interview, 6 January 2014). ${ }^{22}$

\footnotetext{
${ }^{21}$ For further information on the theory of seven-year cycles, see these three collected works of Steiner's lectures: Steiner (1991), (2004), and (2011). For secondary sources, see Uhrmacher (1995) and Quiroga \& Igelmo (2013).

${ }^{22}$ The first was the introductory course taught by Stewart C. Easton at a university college in Madrid in 1978. Periodic summer courses were developed later on. The first courses were held in Cóbreces (Santander), the second and third in Comillas (Cantabria), the next one in Jaca (Huesca), and the last one in Vilaller (Lérida).
} 
These courses led to the founding of a set of small-scale initiatives in the early 1980s. Few of them lasted long, such as the ones started in Galicia and in Zaragoza (A. Gómez, interview, 11 February 2014). Two of them did, however: the Associació d'escoles Waldorf, which was created in Barcelona in 1981, and the Asociación de Colegios Waldorf in Alicante, ${ }^{23}$ the earliest record of which dates to 1982 (Berlin, 1982, p. 48). In both cases, the first steps taken by these initiatives were small and slow in comparison with the Jardín de Infancia Micael in Madrid. As the movement in Waldorf pedagogy grew in the 1990s, the need arose of training teachers in Spain. The first course was held in 1991 and lasted three years. Later, in 1997, an intensive one-year course started. It was focused on early childhood education (K. Armbruster, interview, 22 May 2015). In 2001, these two courses merged and the one still being offered was created: the "Training Course on Waldorf Pedagogy and Humanistic-Artistic Education" (Curso de Formación en Pedagogía Waldorf y Formación Humanístico-Artística).

What is relevant about this fact is that being able to train teachers in Spain brought about greater possibilities and independences in the opening of schools, since it was no longer necessary to move abroad for at least a year to be trained in this pedagogy. This three-year course is the one that brings together the greatest number of participants and is given at the Escuela Libre Micael, where the Training Center is located. Every three years, 150 people are trained in Waldorf pedagogy, divided into three specialties: Early Childhood Education, Primary Education, and Secondary/High School Education. Moreover, this degree is accredited by the Ministry of Education and Science, specifically by the Instituto Superior de Formación del Profesorado, Investigación e Innovación Educativa (Higher Institute of Teacher Training, Research and Educational Innovation) (Centro de Formación en Pedagogía Waldorf, 2015). Because of the track record of this course and the fact that it gathers a larger number of participants than any other in Spain, ${ }^{24}$ it warrants a more detailed analysis below.

Starting with how the contents progress in the Waldorf Pedagogy and Humanistic-Artistic Training Course, one important feature is that during the first year, the work is on anthroposophy in general and its different applications, such as in education, medicine, agriculture, biographic work, architecture, and Social Threefolding and its implementation in social organisms. This first year is also a time for developing different artistic workshops. Thus, participants take classes in sculpting, watercolor painting and charcoal sketching, theatre, music, word arts, mask-making, and eurhythmy. Once this basis is acquired, the second and third year courses focus directly

\footnotetext{
They each lasted roughly one week. The teachers that gave lectures and workshops were mostly from Germany, although some were from France and England. Three years after the course in Vilaller and in clear continuity with those courses, the VI Encuentro Antroposófico de Verano en España was held (Quiroga, 2015).

${ }^{23}$ In Spain, initiatives in Waldorf pedagogy often got their start as associations that carried out activities linked to Waldorf pedagogy. Over time, as the number of students increased, the official kindergarten was subsequently created.

${ }^{24}$ There are currently six other Waldorf teacher training centers: the Associació per a la pedagogía Steiner/Mallorca in the Balearic Islands, the Asociación Escuela Libre "La casa del sol" in the Canary Islands, 0 lar de Ávalon in Galicia, the Centro de Formación Waldorf Vitoria-Gasteiz in the Basque Country, and the Escuela Waldorf de Alicante in the Valencian Community (Asociación de Centros Educativos Waldorf-Steiner de España, 2015).
} 
on the methodology and teaching of subject matter in Waldorf pedagogy. These two years are for having time to go deeper into the Anthroposophical concepts present in education (Centro de Formación en Pedagogía Waldorf, 2015).

One curious point regarding how the day is structured in this training course is the fact that it continues on with how Steiner structured it in 1919. Thus, the early hours of the morning are used for the most intellectual part, which usually consists of listening to a lecture and having a colloquium. After lunch come various types of workshops, since it is considered to be the most suitable time for relaxed, creative activities (what anthroposophical terminology calls "rythmias"). In the first year, these workshops are of the above-mentioned arts. In the second and third years, the subject matter of the workshops revolves around teaching the specific subject matter at each grade level. Thus, it may range from infant nutrition, illnesses, and handicrafts for kindergarten teachers; watercolors, mathematics, and zoology for primary school; and literature, chemistry, or woodworking for secondary and baccalaureate teachers.

The people who usually enroll in this training course come from a variety of backgrounds but they all share a degree of questioning how the official normative society plays out. There are parents whose children attend Waldorf education centers, so the parents take part in the course motivated by getting a deeper understanding of the fundamentals of this pedagogy. Teachers who are carrying out their work in Waldorf schools also enroll; in Spain, not having completed this training course is not a hindrance to working at a school, Waldorf or otherwise. For the latter, they are usually teachers who aspire to including some of the features of this pedagogy in their classrooms and perhaps join up with the network of Waldorf schools. Along with them are people interested in anthroposophy and/or Waldorf pedagogy but whose professional ties are not in the field of education. The participants in the course find it quite interesting to have the chance to learn a pedagogy whose underpinnings differ so greatly from the more official model, its practical and artistic component, and the search for an education based on certain notions of spirituality. However, despite the interest that arises from the "different" nature of this pedagogy, the participants often find the system to be quite closed and anchored to teaching practices viewed as overly traditional (the role of the teacher, the presence of subjects, the scarce integration of information and communication technology, and so on). Moreover, the excessive focus of the course on anthroposophical knowledge and how the pedagogical process develops makes contextual study of the historical underpinnings of this educational theory less likely, which sometimes prevents participants from gaining an overall contextualized view of Waldorf pedagogy. ${ }^{25}$

\footnotetext{
${ }^{25}$ One of the underpinnings worth mentioning is the meaning of the creation of Waldorf pedagogy in the historical stage of the Consciousness Soul: the link between anthroposophy and theosophy, and especially, the "Akasha Chronicle" (a chronicle of everything that happens in the universe is recorded in the ether) in articulating the Waldorf curriculum, as well as the theory of recapitulation, the presence of the school of thought of German idealism and the notion of Bildung, and the context of renewal in the pedagogic methods in which Steiner lived and in which the New School movement was thriving (Quiroga, 2015).
} 
Regarding the lecturers, it must be said that there is a balanced mix of Spanish and foreign teachers. This current balance reflects the growth of Waldorf pedagogy in Spain and its late reception. As a result of the consolidation of this pedagogy over the last decade in Spain, the teacher training courses have diversified. Some initiatives derive from the creation of networks of Waldorf teachers in collaboration with Portugal and Latin America, with the common denominator being their linguistic closeness. For example, this has led to two periodically held meetings: the annual El Encuentro Ibérico de Educadores y Profesores Waldorf de España y Portugal, and the Encuentro Iberoamericano de Pedagogía Waldorf held every three years. Both events are conceived as spaces where Waldorf teachers can hone their professional skills while meeting teachers from other geographical contexts, thereby enriching their classroom teaching.

\section{Conclusions}

Waldorf pedagogy is a "signature pedagogy" based on the philosophy of Rudolf Steiner. In general terms, it can be said that Steiner was convinced that the answer to the great social problems of his time and of the future, including education, would be solved if mankind could integrate knowledge of anthroposophy - the esoteric philosophy he founded in 1913. Six years later, the first educational center was inaugurated in the heart of the anthroposophical movement: the Freie Waldorfschule in Stuttgart. The need to train future teachers in a way that anthroposophy could be applied to education motivated Steiner to train that first faculty by means of a course prior to the inauguration of the school. As indicated above, the training of Waldorf teachers may well be conceptualized as an initiation into acquiring an anthroposophical perspective on education and on human beings.

The options for teacher training in Waldorf pedagogy today are heterogeneous, depending on each country. They are mostly organized from within the movement, although they have dual approval (from the movement and from the government institutions in the country). The profile of teacher trainers is usually that of people with extensive knowledge of anthroposophy and its pedagogy, and a long involvement with Waldorf centers. For their part, some participants may sometimes need to meet admission prerequisites. The courses generally span a long time. This is due to the idea that being a Waldorf teacher means taking a road to inner development that helps the future teacher gradually become familiar with an esoteric-spiritual vision of human beings and an education that fits it accordingly. In the case of Spain, an analysis was done on the "Training Course on Waldorf Pedagogy and Humanistic-Artistic Education" taught at the training center at the Escuela Libre Micael (Madrid). In consonance with all this, it is a three-year course that delves deeper into anthroposophy and its pedagogic application.

In clear continuity with the course taught by Steiner in 1919, the Waldorf teacher training courses today are conceived as a specific type of training. Thus, the schoolteachers must hold a university degree and one issued by the Waldorf institute. The need for complementary training makes sense in that the main objective has been 
the same throughout the history of this pedagogy: to establish anthroposophy as a foundation for educational action. This goal implies that teachers acquire and integrate knowledge of anthroposophy and base their pedagogical practice on it.

\section{References}

Asociación de Centros Educativos Waldorf-Steiner de España (2015). Centros Educativos Waldorf. Revista Waldorf-Steiner Educación, 21, 3.

Berlín, J. (1982). Centros de información. Boletín de Metodología para los presentes y futuros maestros Waldorf, 94, 48.

Blom, P. (2010). Años de vértigo. Cultura y cambio en Occidente, 1900-1914. Barcelona, Spain: Anagrama.

Centro de Formación en Pedagogía Waldorf. Nuevos cursos. http://www.centrowaldorf.com/cursos.htm

Easton, S. C. (1984). El hombre y el mundo a la luz de la antroposofía. Madrid, Spain: Editorial Rudolf Steiner.

European Network for Academic Steiner Teacher Education (ENASTE). http://www.enaste.com/enaste.htm

Freie Hochschule Stuttgart-Seminar für Waldorfpädagogik. International English Masters Programme at the Freie Hochschule Stuttgart (Waldorf Teachers College). http://www.freie-hochschule-stuttgart.de/english version/

Freunde der Erziehungskunst Rudolf Steiners. Waldorf Worldwide List. https://www.freunde-

waldorf.de/fileadmin/user upload/images/Waldorf World List/Waldorf World List.pdf

Hartlieb, F. (1928). The Free Waldorf School at Stuttgart. London, England: Anthroposophical Publishing Company.

Hobsbawm, E. (2012). La era del imperio (1875-1914). Barcelona, Spain: Crítica, Libros de Historia.

Kullak-Ublick, H. (2014). Haager Kreis - Internationale Konferenz der Waldorfpädagogischen Bewegung. 9th World Teacher's Conference. http://www.haager-kreis.org/en/current/

Livingstone, D. (2004). Cultures of Science. In J. S. Duncan, N. C. Johnson, \& R. H. Schein (Eds.), A companion to cultural geography (pp. 139-150). Oxford, England: Blackwell Publishing.

Murphy, C. (Ed.) (1991). Emil Molt and the beginnings of the Waldorf School Movement: Autobiographical sketches. Edinburgh, Scotland: Floris Books.

Quintana, J. M. (2013). Pensamiento pedagógico en el idealismo alemán y en Schleiermacher. Madrid, Spain: Universidad Nacional de Educación a Distancia.

Quiroga, P., \& Igelmo, J. (2013). La pedagogía Waldorf y el juego en el jardín de infancia: Una propuesta teórica singular. Bordón, 56(1), 79-92.

Quiroga, P. (2014). La pedagogía Waldorf: Origen, consolidación internacional y 
principios educativos. In J. L. Hernández Huerta, J. Quintano Nieto, \& S. Ortega Gaite (Eds.). Utopía y educación: Ensayos y estudios (pp. 55-77). Salamanca, Spain: FahrenHouse.

Quiroga, P. (2015). The reception of Waldorf Education in Spain (PhD dissertation). Universidad Complutense de Madrid.

Quiroga, P., \& Girard, O. (2015). La expansión internacional de la pedagogía Waldorf: Un análisis histórico. Temps d'educació, 48, 11-28.

Staudenmaier, P. (2014). Between occultism and Nazism: Anthroposophy and the politics of race in the fascist era. Leiden, Netherlands: Koninklijke Brill NV.

Steiner, R. (1919). Address given by Dr. Rudolf Steiner, Stuttgart, 20 th August 1919, On the occasion of a welcoming meeting for the participants of the pedagogical courses held from $21^{\text {st }}$ August till $6^{\text {th }}$ September for the future Waldorf teachers. In E. Gabert (Ed.). (1986). Rudolf Steiner's Conferences with the teachers of the Waldorf School in Stuttgart, 1919-1920 (pp. 34-35). Forest Row, England: Steiner Schools Fellowship Publications.

Steiner, R. (1991). La educación del niño: Metodología de la enseñanza. Madrid, Spain: Editorial Rudolf Steiner.

Steiner, R. (2002). Cómo conocer los mundos superiores. Madrid, Spain: Editorial Rudolf Steiner.

Steiner, R. (2004). El segundo septenio: Fundamentos pedagógicos para el saludable desarrollo del ser humano. Buenos Aires, Argentina: Editorial Antroposófica.

Steiner, R. (2006). Fundamentos de la educación Waldorf II: Metodología y Didáctica. Madrid, Spain: Editorial Rudolf Steiner.

Steiner, R. (2008). La educación como cuestión social. Limache, Chile: Cuadernos Pau de Damasc.

Steiner, R. (2010). Coloquios pedagógicos y conferencias curriculares. Limache, Chile: Cuadernos Pau de Damasc.

Steiner, R. (2011). El primer septenio: La educación preescolar según Rudolf Steiner. Madrid, Spain: Editorial Rudolf Steiner.

Steiner, R. (2014). Fundamentos de la educación Waldorf I: El estudio del hombre como base de la pedagogía. Madrid, Spain: Editorial Rudolf Steiner.

Uhrmacher, B. (1995). Uncommon schooling: A historical look at Rudolf Steiner, anthroposophy, and Waldorf Education. Curriculum Inquiry, 25(4), 381-406. doi: $10.2307 / 1180016$

Van Oort, H. (2011). Anthroposophy A-Z: A glossary of terms relating to Rudolf Steiner's spiritual philosophy. Forest Row, England: Rudolf Steiner Press.

Werner, U., \& von Plato, B. (2001). Waldorf education: Expansion in the twentieth century. In N. Göbel \& S. Heuser (Eds.), Waldorf Education worldwide (pp. 24-33). Berlin, Germany: Friends of Waldorf Education. 